\title{
Hubungan Kadar Vitamin D dan Gangguan Fungsi Hati pada Pasien Hepatitis B Kronik
}

\author{
Sherin Alifia Hendri ${ }^{1}$, Arfianti $^{2 *}$
}

\begin{abstract}
Vitamin D plays an important role in the pathogenesis of chronic hepatitis B (CHB) through regulating immune response. This study aimed to determine the relationship between vitamin D levels and impaired liver function in CHB patients. This was an observational analytical study conducted from March to October 2019. We included 36 CHB patients aged $38.31 \pm 12.98$ years and consisted of 16 men and 20 women. Vitamin D levels were measured by enzyme-linked immune assay (ELISA) method while albumin and bilirubin levels were examined by colorimetric assay. Vitamin D levels were in normal limits in $80.6 \%$ and insufficiency/deficiency in $19.4 \%$ of CHB patients. ALBI ratio scores were good in $75 \%$ and moderate-poor in $25 \%$ of subjects. Furthermore, there was no significant association between vitamin $\mathrm{D}$ levels and the ALBI ratio. In conclusion, this study shows that there is no relationship between plasma vitamin D levels and impaired liver function in CHB patients.
\end{abstract}

Keywords: ALBI ratio, albumin, bilirubin, chronic hepatitis B, vitamin D

Hepatitis B merupakan proses inflamasi dan nekrosis jaringan parenkim hati yang disebabkan oleh virus hepatitis B (VHB). Virus hepatitis B merupakan virus DNA yang termasuk golongan Hepadnaviridae. ${ }^{1}$ Sebesar $10-20 \%$ penderita hepatitis B kronik (HBK) memiliki risiko untuk berlanjut menjadi sirosis hati, $20-30 \%$ dari sirosis akan mengalami dekompensasi hati dan 5-15\% penderita sirosis kompensata berisiko menderita karsinoma hati. Penularan VHB dapat terjadi melalui kontak dengan cairan tubuh pasien yang terinfeksi VHB maupun secara perkutaneus. Pola penularan infeksi VHB di negara endemis seperti Indonesia pada umumnya dari ibu ke anak saat proses persalinan (penularan vertikal). ${ }^{2}$

Infeksi VHB merupakan salah satu masalah kesehatan global oleh karena dua milyar orang diperkirakan telah terinfeksi VHB dan 257 juta orang diantaranya merupakan penderita hepatitis B kronik yang memiliki risiko tinggi mengalami penyakit hati progresif. ${ }^{3}$ Prevalensi infeksi VHB di Indonesia sangat bervariasi yaitu berkisar antara 4\%

\footnotetext{
* Corresponding author: evi anti@yahoo.com

1 Program Studi Kedokteran Fakultas Kedokteran Universitas Riau, Pekanbaru, Riau, Indonesia

2 KJFD Biologi Kedokteran Fakultas Kedokteran Universitas Riau, Pekanbaru, Riau, Indonesia
}

hingga $20.3 \%{ }^{4}$ Prevalensi paling tinggi dilaporkan di Kota Makassar (7.1\%), dan prevalensi paling rendah berada di Kota Jakarta $(4.0 \%) .{ }^{5}$ Indonesia dikategorikan sebagai negara endemik hepatitis B dengan endemisitas menengah sampai tinggi. Hasil Riset Kesehatan Dasar (Riskesdas) tahun 2013 menunjukkan indikasi penurunan prevalensi hepatitis B secara nasional dari $9,4 \%$ pada tahun 2007 menjadi 7,1\% di tahun 2013. ${ }^{6}$ Menurut Profil Kesehatan Indonesia yang dilaporkan oleh Kementerian Kesehatan Republik Indonesia pada tahun 2018, persentase ibu hamil dengan hepatitis $B$ surface antigen (HBsAg) reaktif paling banyak dilaporkan dari Nusa Tenggara Timur $(5,53 \%)$ dan disusul oleh Maluku Utara (4,52\%), sedangkan persentase ibu hamil dengan HBsAg reaktif di Riau sebesar $1,69 \%{ }^{7}$

Virus hepatitis B merupakan virus hepatotropik yang tidak bersifat sitopatik secara langsung. Proses inflamasi dan kerusakan hati pada infeksi VHB merupakan dampak dari respon imun terhadap invasi virus. Respon imun terhadap antigen VHB dimediasi oleh interaksi kompleks antara sistem imun bawaan dan dapatan yang bertanggung jawab pada clearance virus dan perjalanan penyakit. ${ }^{8}$ Pasien dengan hepatitis B kronik dapat mengalami gangguan fungsi hati, yang akan berdampak pada kemampuan hati 
untuk mensintesis albumin dan memetabolisme bilirubin. Penurunan kadar serum albumin atau peningkatan kadar serum bilirubin merupakan salah satu penanda penyakit hati lanjut atau bahkan sirosis. ${ }^{9}$ Bilirubin merupakan produk akhir dari katabolisme hemoglobin, peningkatan dari bilirubin serum dapat ditemukan dan dapat mengindikasikan kerusakan hati yang lebih lanjut pada pasien yang sebelumnya telah terbukti terinfeksi VHB. ${ }^{10}$ Tingkat keparahan dari disfungsi hati dapat diketahui melalui skor fungsi hati yaitu ratio albumin-bilirubin (ALBI) dengan mengkombinasikan kadar serum albumin (Alb) dan serum total bilirubin (T-bil). Berdasarkan nilai ratio ALBI, derajat fungsi hati diklasifikasikan menjadi tiga derajat yang menunjukkan tingkat prognosis, yaitu derajat 1 dengan nilai $\leq-2.60$ (prognosis baik), derajat 2 dengan nilai -2.60 sampai $\leq-1.39$ (prognosis sedang) dan derajat 3 dengan nilai $>-1.39$ (prognosis buruk). Skor ALBI dapat digunakan dalam menentukan tingkat keparahan dari fibrosis hati terkait dengan infeksi VHB, membedakan antara sirosis dan non sirosis, serta secara khusus memprediksi prognosis pasien hepatitis B dengan sirosis dan karsinoma hati. ${ }^{11,12}$

Vitamin D memiliki fungsi utama dalam pengaturan absorpsi kalsium di usus halus dan regulasi kadar kalsium melalui resorpsi di tulang. Selain itu, vitamin D juga memiliki peran dalam regulasi sistem imun alamiah dan dapatan melalui ikatan dengan reseptor vitamin D (RVD). Penelitian terdahulu menyebutkan bahwa vitamin $\mathrm{D}$ berperan dalam patogenesis berbagai penyakit seperti tuberkulosis, penyakit jantung koroner, diabetes atau resistensi insulin, kanker, dan penyakit hati kronik termasuk hepatitis $\mathrm{C}$ dan hepatitis B kronik. ${ }^{13}$ Vitamin D memiliki dua prekursor biologis utama yaitu vitamin D3 (cholecalciferol) yang berasal dari sinar ultraviolet dan vitamin D2 (ergocalciferol) yang berasal dari makanan. Kedua prekursor tersebut kemudian dikonversi menjadi 25-hydroxyvitamin $D$ [25(OH)D] (kalsidiol) ketika memasuki hati. Untuk menjadi aktif secara biologis, perlu dilakukan hidroksilasi tambahan di dalam ginjal menghasilkan 1,25-dihidroksivitamin D aktif [1,25 (OH)2D] (calcitriol), yang kemudian akan beredar dalam darah sebagai hormon untuk mengatur kadar kalsium dan fosfat, serta untuk mendorong pertumbuhan yang sehat serta proses remodelling tulang. ${ }^{14,15}$
Beberapa penelitian telah menyebutkan terdapat hubungan antara insufisiensi vitamin $\mathrm{D}$ dan manifestasi klinis serta progresivitas infeksi VHB dan virus hepatitis $\mathrm{C}$ (VHC). Penderita hepatitis $B$ yang mengalami defisiensi vitamin $\mathrm{D}$ memiliki tingkat viremia yang lebih tinggi dibanding penderita dengan kadar vitamin D yang normal. ${ }^{13} \mathrm{Hal}$ ini mengindikasikan peran vitamin $D$ dalam mengontrol replikasi virus. Kondisi insufisiensi vitamin D pada penderita dengan infeksi VHB dan VHC berkisar antara $16-100 \%$. Selain itu kadar vitamin D berbanding lurus dengan kadar albumin dan hitung platelet, tetapi berkorelasi negatif dengan kadar ALT pada fase aktif hepatitis B. Namun, studi lain tidak menemukan adanya hubungan yang bermakna antara status vitamin D dengan parameter fungsi hati pada penderita hepatitis B kronik. Hal ini menunjukkan keterlibatan vitamin $\mathrm{D}$ pada perjalanan penyakit hepatitis B kronik masih kontroversial dan masih perlu penelitian lebih lanjut. ${ }^{15}$

Saat ini, penelitian mengenai hubungan kadar vitamin D plasma terhadap derajat gangguan fungsi hati pada pasien hepatitis B kronik belum pernah dilakukan di Indonesia, khususnya di Provinsi Riau. Maka dari itu, peneliti tertarik untuk meneliti mengenai hubungan antara kadar vitamin D plasma dan derajat gangguan fungsi hati berdasarkan ratio ALBI pada pasien penderita hepatitis B kronik di Poli Penyakit Dalam Rumah Sakit Umum Daerah (RSUD) Arifin Achmad Provinsi Riau.

\section{METODE}

Penelitian ini merupakan penelitian analitik observasional dengan pendekatan cross-sectional yang bertujuan untuk mengetahui hubungan antara kadar vitamin $D$ plasma dan derajat gangguan fungsi hati berdasarkan ratio ALBI pada pasien hepatitis B kronik. Populasi dari penelitian ini adalah seluruh pasien hepatitis B kronik di Poli Penyakit Dalam RSUD Arifin Achmad Provinsi Riau selama periode Maret - Oktober 2019. Sampel pada penelitian ini adalah pasien hepatitis B kronik di Poli Penyakit Dalam RSUD Arifin Achmad Provinsi Riau Periode Maret - Oktober 2019 yang memenuhi kriteria inklusi dan eksklusi. Kriteria inklusi pada penelitian ini adalah pasien yang berumur $>18$ tahun yang bersedia menjadi subjek penelitian ini dengan menandatangani informed consent. Kriteria 
eksklusi pada penelitian ini adalah pasien yang mendapat suplemen vitamin D dan pasien dengan gangguan sintesis albumin seperti gangguan fungsi ginjal. Besar sampel pada penelitian ini dihitung berdasarkan rumus sampel penelitian cross sectional pada pasien hepatitis B kronik dan didapatkan jumlah sampel minimum yaitu 36 orang. Pengambilan sampel dalam penelitian ini menggunakan darah penderita sebanyak $10 \mathrm{ml}$ pada fossa cubitti dan pemeriksaan kadar 25-hydroxyvitamin $D$ di Laboratorium Penelitian Terpadu Fakultas Kedokteran Universitas Riau dengan menggunakan metode enzyme-linked immuno assay (ELISA) sedangkan kadar albumin dan bilirubin total diukur dengan metode colorimetric assay. Kadar vitamin D dikategorikan menjadi normal $(>30 \mathrm{ng} / \mathrm{mL})$, insufisiensi $(20-30 \mathrm{ng} / \mathrm{mL})$ dan defisiensi $(<20 \mathrm{ng} /$ $\mathrm{mL}$ ). Ratio ALBI dikategorikan menjadi tiga derajat yang menunjukkan tingkatan prognosis. Derajat 1 dengan nilai $\leq-2.60$ (prognosis baik), derajat 2 dengan nilai -2.60 sampai $\leq-1.39$ (prognosis sedang), dan derajat 3 dengan nilai $>-1.39$ (prognosis buruk). ${ }^{11}$ Selanjutnya data yang diperoleh dianalisis dengan menggunakan uji univariat dan uji bivariat. Uji bivariat dilakukan untuk mengetahui hubungan antara kadar vitamin D plasma dan derajat gangguan fungsi hati berdasarkan ratio ALBI pada pasien hepatitis B kronik menggunakan uji Fisher's Exact. Uji dikatakan bermakna apabila $P$ value $<0,05$. Penelitian ini telah lulus kaji etik oleh Unit Etika Penelitian Kedokteran dan Kesehatan Fakultas Kedokteran Universitas Riau dengan nomor B/071UN19.5.1.1.8/UEPKK/2020.

\section{HASIL}

\section{Distribusi Subjek Penelitian}

Penelitian ini melibatkan 36 penderita hepatitis B kronik yang direkruit dari Poli Penyakit Dalam RSUD Arifin Achmad Provinsi Riau antara bulan Maret - Oktober 2019. Profil subjek penelitian dapat dilihat pada Tabel 1.

Tabel 1. Profil Subjek Penelitian

\begin{tabular}{lcc}
\hline \multicolumn{1}{c}{ Variabel penelitian } & $\mathbf{N}$ & $\mathbf{\%}$ \\
\hline Usia & & \\
18-40 tahun & 22 & 61,1 \\
$\quad>40$ tahun & 14 & 38,9 \\
Jenis Kelamin & 16 & 44,4 \\
$\quad$ Laki-laki & 20 & 55,6 \\
$\quad$ Perempuan & & \\
Diagnosis & 34 & 94,4 \\
HBK tanpa komplikasi & 2 & 5,6 \\
HBK dengan Sirosis & 0 & 0 \\
HBK dengan hepatoma & & \\
Albumin & 28 & 77,8 \\
$\quad$ Normal $(3.5-5 \mathrm{~g} / \mathrm{dL})$ & 0 & 22,2 \\
Meningkat $(>5 \mathrm{~g} / \mathrm{dL})$ & 8 & 83,3 \\
Menurun $(<3.5 \mathrm{~g} / \mathrm{dL})$ & 30 & 16,7 \\
Bilirubin & 6 & \\
Normal $(\leq 1.2 \mathrm{mg} / \mathrm{dL})$ & Meningkat $(>1.2 \mathrm{mg} / \mathrm{dL})$ &
\end{tabular}

Berdasarkan Tabel 1, sebagian besar subjek berusia antara $18-40$ tahun $(61,1 \%)$ dan terdiri dari perempuan sebanyak 20 orang $(55,6 \%)$ dan laki-laki sebanyak 16 orang $(44,4 \%)$. Sebagian besar pasien dalam penelitian ini terdiagnosis hepatitis B kronik (HBK) tanpa komplikasi (94,4\%), hanya sebagian kecil pasien yang terdiagnosis HBK dengan sirosis $(5,6 \%)$ dan tidak ada pasien yang terdiagnosis HBK dengan hepatoma. Pasien dengan kadar albumin normal sebanyak 28 orang $(77,8 \%)$, rendah sebanyak
8 orang $(22,2 \%)$ dan tidak ditemukan pasien dengan kadar albumin meningkat. Kadar bilirubin normal ditemukan pada 30 pasien $(83,3 \%)$ dan meningkat pada 6 pasien $(16,7 \%)$.

\section{Gambaran Derajat Gangguan Fungsi Hati}

Hasil pemeriksaan gangguan fungsi hati berdasarkan ratio ALBI pada 36 subjek dapat dilihat pada Tabel 2. 
Sherin Alifia Hendri,dkk, Hubungan Kadar Vitamin D dan Gangguan Fungsi Hati pada Pasien Hepatitis B Kronik

Tabel 2. Gambaran Derajat Gangguan Fungsi Hati

\begin{tabular}{lcc}
\hline \multicolumn{1}{c}{ Ratio ALBI } & N & \% \\
\hline Baik & 27 & 75 \\
Sedang-Buruk & 9 & 25 \\
\hline
\end{tabular}

Berdasarkan ratio ALBI pada Tabel 2 sebanyak 27 pasien (75\%) memiliki fungsi hati baik (derajat 1), dan hanya 9 pasien (25\%) yang memiliki derajat gangguan fungsi hati yang sedang-buruk (derajat 2-3).

Tabel 3. Gambaran Kadar Vitamin D Plasma

\section{Gambaran Kadar Vitamin D Plasma}

Pemeriksaan kadar vitamin D plasma pada 36 subjek dilakukan dengan metode ELISA dan dibaca absorbansinya menggunakan spektrofotometer. Setelah mengetahui kadar vitamin D, dilakukan analisis untuk mengetahui gambaran kadar vitamin D plasma pada subjek penelitian yang dapat dilihat pada Tabel 3.

\begin{tabular}{lcc}
\hline \multicolumn{1}{c}{ Kadar Vitamin D } & N & \% \\
\hline Normal & 29 & 80,6 \\
Insufisiensi-Defisiensi & 7 & 19,4 \\
\hline
\end{tabular}

Berdasarkan Tabel 3, sebanyak 80,6\% pasien memiliki kadar vitamin D yang normal dan hanya $19,4 \%$ pasien yang mengalami insufisiensi hingga defisiensi vitamin D.

\section{Hubungan antara Kadar Vitamin D Plasma dan Derajat Gangguan Fungsi Hati}

Hubungan antara kadar vitamin D plasma dan derajat gangguan fungsi hati berdasarkan ratio ALBI pada subjek penelitian dapat dilihat pada Tabel 4.

Tabel 4. Hubungan antara Kadar Vitamin D Plasma dan Ratio ALBI

\begin{tabular}{|c|c|c|c|c|c|c|c|}
\hline \multirow{3}{*}{ Kadar Vitamin D } & \multicolumn{4}{|c|}{ Skor ratio ALBI } & \multirow{3}{*}{ OR } & \multirow{3}{*}{$95 \% \mathrm{CI}$} & \multirow{3}{*}{$p$ value } \\
\hline & \multirow{2}{*}{\multicolumn{2}{|c|}{ Sedang-Buruk }} & \multicolumn{2}{|c|}{ Baik } & & & \\
\hline & & & $\mathrm{n}$ & $\%$ & & & \\
\hline Insufisiensi-Defisiensi & 1 & $14,3 \%$ & 6 & $85,7 \%$ & & $0.045-$ & \\
\hline Normal & 8 & $27,6 \%$ & 21 & $72,4 \%$ & 0.438 & 4.227 & 0.652 \\
\hline
\end{tabular}

Berdasarkan Tabel 4.4, dari penderita hepatitis B kronik yang mengalami insufisiensi-defisiensi vitamin $\mathrm{D}, 1$ orang $(14,3 \%)$ dengan skor ratio ALBI sedang-buruk (derajat 2-3) dan 6 orang $(85,7 \%$ ) dengan skor ALBI baik (derajat 1). Sebanyak 8 orang $(27,6 \%)$ penderita hepatitis B kronik dengan kadar vitamin D normal memperlihatkan skor ALBI yang sedang-buruk dan 21 orang $(72,4 \%)$ dengan skor ALBI baik. Berdasarkan uji statistik, didapatkan hasil bahwa tidak terdapat hubungan antara kadar vitamin D plasma dan skor rasio ALBI pada penderita hepatitis B kronik di RSUD Arifin Achmad Provinsi Riau $(\mathrm{OR}=0.438 ; 95 \% \mathrm{CI}=0.045-4.227$; $p$ value $=0.796)$.

\section{PEMBAHASAN}

Berdasarkan penelitian ini, didapatkan bahwa sebagian besar pasien dengan hepatitis B kronik berusia antara $18-40$ tahun $(61,1 \%)$ dengan jenis kelamin yang didominasi oleh perempuan yaitu sebanyak 20 orang $(55,6 \%)$. Sejalan dengan penelitian yang dilakukan di Rwanda, populasi dengan HBsAg positif paling banyak ditemukan pada kelompok usia 35-44 tahun dan 45-54 tahun. ${ }^{16}$ Rerata usia pada penelitian ini lebih muda dibandingkan dengan penelitian cross-sectional yang dilakukan Pradnyawati et. al tahun 2018 terhadap 75 subjek penderita hepatitis B, dimana rerata usia penderita adalah $46,1 \pm 14,09$ tahun, namun terdapat perbedaan pada distribusi jenis 
kelamin, dimana pada penelitian tersebut lebih dominan berjenis kelamin laki-laki $(72 \%) .{ }^{17}$

Berdasarkan penelitian Jia et. al tahun 2019 terhadap 478 responden dengan infeksi VHB kronik, rerata usia penderita adalah 41,01 $\pm 14,31$ tahun dengan jenis kelamin laki-laki sebesar 53,1\% dan perempuan sebesar $46,9 \%$. Jenis kelamin dan usia sangat penting dalam menentukan diagnosis, pilihan terapi dan penentuan kerusakan hati. ${ }^{18}$ Penelitian Muljono tahun 2017 pada populasi Indonesia, menyatakan bahwa tidak terdapat perbedaan signifikan antara kelompok usia subjek dengan distribusi HBsAg positif. ${ }^{6}$ Studi klinis yang dilakukan oleh Ayele tahun 2012 pada 120 pasien yang memenuhi kriteria dan memiliki tanda dan gejala penyakit hati kronik, prevalensi $\mathrm{HBsAg}$ ditemukan sebesar 35,8\% dengan jenis kelamin terbanyak yaitu laki-laki $(38,2 \%)$ dibandingkan perempuan $(31,8 \%)$, namun perbedaannya tidak signifikan secara statistik $(p$ value $=0.556) .{ }^{19}$

Lebih dari $80 \%$ pasien karsinoma hati merupakan penderita hepatitis B atau C kronik. Selain viral load, jenis kelamin, usia dan status ekspresi $\mathrm{HBe} A g$ dilaporkan memengaruhi progresivitas infeksi. Laki-laki memiliki risiko lebih tinggi untuk berkembang menjadi karsinoma hati dibandingkan wanita, hal ini erat kaitannya dengan hormon seks (androgen dan estrogen). Namun, tidak terdapat perbedaan yang jelas dalam distribusi usia antara laki-laki dan perempuan. ${ }^{20}$ Pasien yang mengalami seroclearance HBsAg sebelum usia 50 tahun dan tidak mengalami sirosis memiliki prognosis yang lebih baik dibandingkan penderita yang mengalami konversi setelah usia 50 tahun, memiliki sirosis atau mengalami ko-infeksi dengan VHC. ${ }^{21}$ Perbedaan rerata usia dan distribusi jenis kelamin pada penelitian ini dibandingkan dengan penelitian yang lain dapat terjadi karena sampel yang terlalu kecil. Untuk menilai progresivitas penyakit hati, selain enzim hati, juga diperlukan pemantauan fungsi sintesis (albumin, waktu protombin), metabolisme bilirubin, dan hitung darah lengkap. ${ }^{9}$ Hasil penelitian ini menunjukkan sebagian besar responden memiliki kadar albumin dan bilirubin yang normal $(77,8 \%$ dan $83,3 \%$ ). Berbeda dengan hasil penelitian Pradnyawati tahun $2018^{17}$ dan Nuraini tahun $2017^{22}$, dimana sebagian besar penderita hepatitis B mengalami penurunan kadar albumin (56\%) dan peningkatan kadar bilirubin total (80\%). Infeksi hepatitis B kronik (HBK) dapat berkembang menjadi sirosis hepatis. Penelitian yang dilakukan oleh Maharani tahun 2018 pada 397 pasien sirosis hepatis yang dirawat inap di RSUD Arifin Achmad Provinsi Riau, didapatkan 90,59\% mengalami peningkatan kadar bilirubin dan 92,34\% mengalami penurunan kadar albumin. ${ }^{23}$ Hati berfungsi sebagai tempat untuk ekskresi bilirubin dan sintesis albumin. Jika terjadi kerusakan hati lanjut seperti sirosis, maka bilirubin tidak dapat diekskresikan melalui urin, sehingga jumlahnya akan berlebih di dalam hati. ${ }^{22}$ Gangguan sintesis albumin yang terjadi pada kerusakan hati juga dapat menyebabkan turunnya kadar albumin dalam darah. ${ }^{9}$ Pada fase imuntoleran infeksi VHB kronik dapat ditemukan serum DNA VHB yang tinggi, namun kadar ALT masih normal dan gambaran histologi hati yang mendekati normal. ${ }^{24}$ Kadar albumin dan bilirubin yang normal pada penelitian ini mungkin terjadi karena sebagian besar sampel masih dalam fase imuntoleran, dimana belum terjadi kerusakan hati lebih lanjut seperti adanya sirosis dan karsinoma hati. Selain itu, jumlah subjek yang relatif sedikit dibanding penelitian lain kemungkinan menyebabkan kemampuan penelitian untuk menemukan perbedaaan yang bermakna menjadi rendah. Selain itu dapat disebabkan jumlah penderita HBK dengan komplikasi sirosis yang sangat kecil dan tidak ada yang mengalami komplikasi hepatoma.

Pada penelitian ini, $75 \%$ pasien memiliki fungsi hati baik (derajat 1), dan hanya $25 \%$ pasien yang memiliki gangguan fungsi hati sedang-buruk (derajat 2-3). Penelitian di China tahun 2017 menemukan bahwa penderita HBK rata-rata memiliki gangguan fungsi hati sedang (derajat 2) dengan rerata nilai $-2.48 .{ }^{25}$ Penelitian yang dilakukan oleh Wang et. al tahun 2019 pada penderita HBK dengan sirosis, dimana pasien dengan derajat 2 lebih banyak ditemukan (62,6\%) dibandingkan derajat $1(20,6 \%)$, dan derajat $3(16,8 \%) .{ }^{26}$ Berbeda dengan penelitian Chen et. al pada 806 pasien HBK dengan sirosis hati, dimana pasien dengan ratio ALBI derajat $3(46,9 \%)$ mendominasi dibandingkan derajat $2(45,2 \%)$ dan derajat $1(7,9 \%) .{ }^{27}$ Lei et. al pada penelitiannya menunjukkan bahwa pasien dengan VHB terkait sirosis hati lebih banyak disertai ratio ALBI derajat 2 (54,62\%) dibandingkan derajat lainnya. Berbeda pada pasien dengan VHB terkait karsinoma hati, dimana ratio ALBI derajat 1 (56,69\%) lebih 
mendominasi dibandingkan derajat lainnya. ${ }^{28}$

Penelitian ini menunjukkan sebagian besar penderita HBK memiliki kadar vitamin D normal (80,6\%), sedangkan yang mengalami insufisiensidefisiensi vitamin D hanya 19,4\%. Sejalan dengan penelitian Yu et. al tahun 2015 pada 242 penderita HBK, ditemukan bahwa sebagian besar $(59,9 \%)$ pasien memiliki kadar vitamin D yang normal, kemudian disusul dengan insufisiensi $(31,4 \%)$ dan defisiensi (8.7\%). ${ }^{28}$ Begitu pula dengan penelitian yang melibatkan 84 penderita HBK di Iran, bahwa sebagian besar sampel $(47,6 \%)$ disertai kadar vitamin $\mathrm{D}$ normal dan disusul oleh insufisiensi (34.5\%) dan defisiensi (17,9\%). ${ }^{29}$ Ilkovska et. al pada penelitiannya terhadap 22 penderita HBK, ditemukan $11(50 \%)$ pasien mengalami defisiensi vitamin D dan hanya $2(9 \%)$ pasien yang memiliki kadar vitamin D normal. ${ }^{30}$ Berbeda dengan penelitian Yu el. al yang lain tahun 2017 pada 560 penderita HBK, dimana 55\% pasien mengalami insufisiensi vitamin D dan $24 \%$ mengalami defisiensi vitamin D. ${ }^{31}$ Insufisiensi vitamin D (47\%) juga lebih dominan dibandingkan defisiensi (34\%) dan kadar vitamin D normal (19\%) pada sebuah studi kohort terhadap 203 penderita HBK di Jerman. ${ }^{29}$ Itokawa et. al, pada penelitiannya tahun 2018 melaporkan bahwa kadar serum vitamin $\mathrm{D}_{3}$ lebih rendah secara signifikan pada pasien HBK daripada individu sehat ( $p$ value $=0.013$ ), dimana sebagian besar pasien HBK mengalami defisiensi vitamin D (47,9\%). Pada penelitian tersebut, status serum vitamin $\mathrm{D}_{3}$ dipengaruhi oleh jenis kelamin dan musim. Namun penelitian tersebut tidak meneliti hubungan status vitamin D dengan kadar bilirubin total. ${ }^{13}$

Pada penelitian ini, 72,4\% subjek dengan kadar vitamin D normal, menunjukkan skor ALBI baik (derajat 1) dan 27,6\% dengan skor ALBI sedang-buruk (derajat 2-3). Sedangkan subjek dengan insufisiensi atau defisiensi vitamin D, $85,7 \%$ memiliki skor ratio ALBI baik dan sisanya memiliki skor ALBI sedang-buruk (14,3\%). Analisis hubungan antara kadar vitamin D plasma dengan derajat gangguan fungsi hati tidak menunjukkan kemaknaan secara statistik. Sejauh pengetahuan peneliti, penelitian mengenai hubungan kadar vitamin $\mathrm{D}$ plasma dengan derajat ratio ALBI masih sangat terbatas. Satu penelitian yang meneliti hubungan status vitamin D dengan kadar albumin dan bilirubin menunjukkan bahwa sebagian besar pasien HBK yang dengan defisiensi vitamin D menunjukkan kadar albumin dalam batas normal $(4,2$ $\mathrm{g} / \mathrm{dL}$ ), namun terjadi peningkatan kadar bilirubin total dengan rerata $15,3 \mathrm{mg} / \mathrm{dl}$. Penurunan kadar albumin dan peningkatan kadar total bilirubin umum ditemukan pada kasus sirosis hati. Menurut penelitian tersebut, kadar vitamin $\mathrm{D}$ berkorelasi negatif dengan konsentrasi DNA VHB. Hal ini mengindikasikan bahwa defisiensi vitamin $\mathrm{D}$ yang sering ditemukan pada penderita HBK kemungkinan berkaitan dengan kegagalan imunitas sel host untuk menekan replikasi virus. ${ }^{32}$

Meskipun beberapa penelitian telah menunjukkan pengaruh status vitamin $\mathrm{D}$ terhadap perjalanan penyakit hepatitis B kronik dan respon terapi antiviral, sampai saat ini belum diketahui secara jelas mekanisme yang mendasari hal ini. Namun dari satu penelitian hewan coba dilaporkan suplementasi vitamin D meningkatkan jumlah sel limfosit $\mathrm{CD}^{+}$, ratio $\mathrm{CD} 4^{+} \mathrm{CD}^{+}$dan proliferasi sel limfosit di jaringan limfa. ${ }^{33} \mathrm{Hal}$ ini diduga meningkatkan fungsi sistem imun dalam menekan replikasi virus hepatitis $B$.

Satu penelitian multisenter yang dilakukan di Cina menganalisis faktor-faktor yang memengaruhi status vitamin D pada penderita hepatitis B kronik. Hasil penelitian ini menunjukkan bahwa penderita hepatitis B kronik berjenis kelamin perempuan, musim panas/gugur, tinggal di daerah yang jauh dari garis ekuator dan memiliki genotipe GC pada polimorfisme gen vitamin $D$ binding protein rs2282679 memiliki risiko lebih besar untuk mengalami defisiensi vitamin D. Penelitian ini juga menemukan adanya penderita dengan kadar vitamin $\mathrm{D} \geq 30 \mathrm{ng} / \mathrm{mL}$ menunjukkan respon terapi yang lebih baik dibanding penderita dengan insufisiensi vitamin D setelah pemberian terapi antiviral. ${ }^{34}$ Selain itu status vitamin D juga dipengaruhi oleh rendahnya paparan sinar UVB pada kulit yang kaya akan melanin (budaya, etnis, pola busana), diet yang rendah komponen vitamin $\mathrm{D}$, dan pekerjaan yang banyak dihabiskan di ruang tertutup. ${ }^{35}$

Studi kohort yang dilakukan Bankuti et. al tahun 2011 terhadap 75 pasien dengan sirosis hati dengan berbagai etiologi, menunjukkan bahwa defisiensi vitamin D sangat lazim ditemukan dan kadar vitamin $\mathrm{D}$ yang rendah berkaitan dengan disfungsi hati dinilai dari skor Child-Pugh (CP) dan 
Model for End-Stage Liver Disease (MELD). Status vitamin $\mathrm{D}$ yang rendah juga merupakan prediktor dari mortalitas dan dekompensasi hati pada kohort tersebut. ${ }^{36}$ Penelitian Zhao et. al tahun 2016 pada 115 penderita HBK dan 115 penderita sirosis hati menemukan hasil bahwa pada sirosis hati, rerata kadar vitamin D lebih rendah, kadar albumin menurun secara signifikan, dan kadar bilirubin total meningkat secara signifikan jika dibandingkan dengan HBK yang masih memiliki kadar albumin dan bilirubin normal. ${ }^{37}$ Sebagian besar sampel pada penelitian kami adalah pasien dengan HBK yang belum berkembang menjadi sirosis maupun karsinoma hati, sejalan dengan penelitian tersebut pada penderita HBK, menunjukkan kadar albumin dan bilirubin dalam batas normal.

Kadar vitamin D serum dipengaruhi oleh beberapa faktor termasuk musim, paparan sinar matahari, letak geografis dan diet. ${ }^{32}$ Penelitian Wong et. al pada 426 penderita hepatitis B kronik menunjukkan bahwa kadar vitamin D serum ditemukan lebih tinggi pada laki-laki, usia muda, hitung platelet dan hitung skor MELD yang rendah. ${ }^{38}$ Indonesia sebagai negara tropis memungkinkan pasien mendapatkan sinar matahari yang lebih banyak daripada negara dengan 4 musim, hal ini mungkin menjadi salah satu faktor sebagian besar sampel pada penelitian ini memiliki kadar vitamin D yang normal. Namun, kadar vitamin D juga tidak luput dari aktivitas dan kebiasaan yang dilakukan oleh orang tersebut. Penelitian mengenai status vitamin D pada populasi Indonesia masih terbatas. Penelitian oleh Rimahardika et. al tahun 2017 yang dilakukan pada 60 pekerja di Jawa Tengah melaporkan bahwa para pekerja yang bekerja diluar ruangan sebagian besar mendapatkan paparan sinar matahari yang sudah cukup (67\%) dibandingkan pekerja yang bekerja didalam ruangan (57\%). Penggunaan jenis pakaian dan sunscreen/sunblock juga memengaruhi asupan vitamin $\mathrm{D}$ yang masuk kedalam tubuh.

Fujita et. al mengemukakan bahwa nilai ratio ALBI yang rendah berkorelasi dengan prognosis penderita karsinoma hati yang lebih baik. ${ }^{11}$ Sehingga, dapat disimpulkan bahwa sebagian besar sampel penderita HBK dalam penelitian memiliki fungsi hati yang baik dan belum berkembang menjadi sirosis bahkan karsinoma hati. Penelitian ini memiliki keterbatasan, antara lain jumlah sampel yang terlalu sedikit sehingga informasi mengenai penyakit hati lain terkait VHB tidak dapat diteliti, kemudian desain studi cross sectional yang dilakukan hanya memungkinkan peneliti mengambil data pada satu waktu saja.

\section{KESIMPULAN}

Subjek penelitian meliputi $94,4 \%$ penderita HBK tidak disertai komplikasi dan hanya 5,6\% yang disertai komplikasi sirosis. Kadar vitamin D dalam batas normal pada $80,6 \%$ dan insufisiensi/defisiensi pada $19,4 \%$ penderita HBK. Skor ALBI baik pada $75 \%$ dan sedang-buruk pada $25 \%$ penderita HBK. Penelitian ini menunjukkan tidak terdapat hubungan antara kadar vitamin D plasma dengan derajat gangguan fungsi hati terhadap penderita hepatitis B kronik.

\section{DAFTAR PUSTAKA}

1. Liang TJ. Hepatitis B: the virus and disease. Hepatology. 2009; 49 (5 Suppl): S13-21.

2. MacLachlan JH, Cowie BC. Hepatitis B virus epidemiology. Cold Spring Harbor perspectives in medicine. 2015; 5 (5): a021410-a021410.

3. Kim H seok, El-Serag HB. The Epidemiology of Hepatocellular Carcinoma in the USA. Curr Gastroenterol Rep. 2019; 21 (4): 17.

4. Mulyanto, Depamede SN, Surayah K, Tsuda F, Ichiyama $\mathrm{K}$, Takahashi $\mathrm{M}$ et al. A nationwide molecular epidemiological study on hepatitis B virus in Indonesia: Identification of two novel subgenotypes, B8 and C7. Archives of Virology. 2009; 154 (7): 1047-1059.

5. Yano Y, Utsumi T, Lusida MI, Hayashi Y. Hepatitis B virus infection in Indonesia. World Journal of Gastroenterology. 2015; 21 (38): 10714-10720.

6. H Muljono D. Epidemiology of Hepatitis B and $\mathrm{C}$ in Republic of Indonesia. Euroasian Journal of Hepato-Gastroenterology. 2017; 7 (1): 55-59.

7 . Kemenkes RI. Profil Kesehatan Indonesia 2018 [Indonesia Health Profile 2018]. 2019.

8. Wang L, Wang K, Zou Z-Q. Crosstalk between innate and adaptive immunity in hepatitis $\mathrm{B}$ virus 
Sherin Alifia Hendri,dkk, Hubungan Kadar Vitamin D dan Gangguan Fungsi Hati pada Pasien Hepatitis B Kronik

infection. World journal of hepatology. 2015; 7 (30): 2980-2991.

9. Rotman Y, Brown TA, Hoofnagle JH. Evaluation of the patient with hepatitis B. Hepatology (Baltimore, Md). 2009; 49 (5 Suppl): S22-S27.

10 .Du M, Zhang S, Xiao L, Xu Y, Liu P, Tang Y et al. The Relationship between Serum Bilirubin and Elevated Fibrotic Indices among HBV Carriers: A Cross-Sectional Study of a Chinese Population. International journal of molecular sciences. 2016; 17 (12): 1-12.

11.Fujita K, Nomura T, Morishita A, Oura K, Yoneyama H, Kobara H et al. Albumin-Bilirubin score differentiates liver fibrosis stage and hepatocellular carcinoma incidence in chronic Hepatitis B virus infection: A retrospective cohort study. American Journal of Tropical Medicine and Hygiene. 2019; 101 (1): 220-225.

12.Johnson PJ, Berhane S, Kagebayashi C, Satomura S, Teng M, Reeves HL et al. A nssessment of liver function in patients with hepatocellular carcinoma: Anew evidence-based approach - The albi grade. Journal of Clinical Oncology. 2015; 33 (6): 550-558.

13 .Itokawa N, Atsukawa M, Tsubota A, Abe H, Shimada N, Okubo T et al. The Relationship Between 25-Hydroxyvitamin $\mathrm{D}_{3}$ and Hepatitis B Surface Antigen Levels in Patients with Chronic Hepatitis B in Japan. Hepatitis Monthly. 2018; 18 (5): e63587.

14 .Iruzubieta P, Terán Á, Crespo J, Fábrega E. Vitamin D deficiency in chronic liver disease. World Journal of Hepatology. 2014; 6 (12): 901-915.

15 .Hoan NX, Van Tong H, Song LH, Meyer CG, Velavan TP. Vitamin D deficiency and hepatitis viruses-associated liver diseases: A literature review. World Journal of Gastroenterology. 2018; 24 (4): 445-460.

16. Makuza JD, Rwema JOT, Ntihabose CK, Dushimiyimana D, Umutesi J, Nisingizwe MP et al. Prevalence of hepatitis B surface antigen (HBsAg) positivity and its associated factors in Rwanda. BMC infectious diseases. 2019; 19 (1): 381-390.
17. Pradnyawati NPW. Analisis Kadar Albumin Serum terhadap Aspartate Trasminase (AST), Alanine Transaminase (ALT) dan Rasio De Ritis pada PAsien Hepatitis B di RSUP Sanglah, Denpasar. E-Jurnal Medika Udayana. 2018; 7 (6): 1-8.

18.Jia J, Li Y, Wei C, Guo R, Xu H, Jia Y et al. Factors associated with disease progression and viral replication in patients with chronic hepatitis B virus infection. Experimental and therapeutic medicine. 2019; 17 (6): 4730-4740.

19 .Ayele AG, Gebre-Selassie S. Prevalence and Risk Factors of Hepatitis B and Hepatitis C Virus Infections among Patients with Chronic Liver Diseases in Public Hospitals in Addis Ababa, Ethiopia. ISRN Tropical Medicine. 2013; 2013: 563821.

20 .Zheng B, Zhu Y-J, Wang H-Y, Chen L. Gender disparity in hepatocellular carcinoma (HCC): multiple underlying mechanisms. Science China Life sciences. 2017; 60 (6): 575-584.

21 .Trepo C, Chan HL, Lok A. Hepatitis B virus infection. Lancet. 2014; 384 (9959): 2053-2063.

22 .Nuraini D, Puspita E. Gambaran Hasil Pemeriksaan Bilirubin Total pada Pasien Hepatitis. Jurnal Insan Cendekia. 2018; 4 (1 SE-Articles): 56-60.

23 .Maharani S, Efendi D, LA. Tampubolon. Gambaran Pemeriksaan Fungsi Hati pada Pasien Sirosis Hepatis yang Dirawat di Rumah Sakit Umum Daerah Arifin Achmad Provinsi Riau Periode 2013-2015. Jurmal Ilmu Kedokteran. 2018; 12 (1): 46-51.

24 .Spinella R, Sawhney R, Jalan R. Albumin in chronic liver disease: structure, functions and therapeutic implications. Hepatology international. 2016; 10 (1): 124-132.

25 .Chen B, Lin S. Albumin-bilirubin (ALBI) score at admission predicts possible outcomes in patients with acute-on-chronic liver failure. Medicine. 2017; 96 (24): e7142.

26. Wang J, Zhang Z, Yan X, Li M, Xia J, Liu Y et al. Albumin-Bilirubin (ALBI) as an accurate and simple prognostic score for chronic hepatitis B-related liver cirrhosis. Digestive and Liver Disease. 2019; 51 (8): 1172-1178. 
27 .Chen R-C, Cai Y-J, Wu J-M, Wang X-D, Song M, Wang Y-Q et al. Usefulness of albumin-bilirubin grade for evaluation of long-term prognosis for hepatitis B-related cirrhosis. Journal of viral hepatitis. 2017; 24 (3): 238-245.

28 . Yu R, Sun J, Zheng Z, Chen J, Fan R, Liang X et al. Association between vitamin $\mathrm{D}$ level and viral load or fibrosis stage in chronic hepatitis B patients from Southern China. Journal of gastroenterology and hepatology. 2015; 30 (3): 566-574.

29 .Farnik H, Bojunga J, Berger A, Allwinn R, Waidmann O, Kronenberger B et al. Low vitamin $D$ serum concentration is associated with high levels of hepatitis B virus replication in chronically infected patients. Hepatology (Baltimore, Md). 2013; 58 (4): 1270-1276.

30 .Ilkovska B, Trifunova B, Hristovska S, Ivanovska M. Vitamin D Levels in Patients with Chronic Hepatitis B, Chronic Hepatitis C, and Health Controls. Journal of IMAB. 2019; 25 (2): 2553-2558.

31.Yu R, Tan D, Ning Q, Niu J, Bai X, Chen S et al. Association of baseline vitamin $\mathrm{D}$ level with genetic determinants and virologic response in patients with chronic hepatitis B. Hepatology Research. 2018; 48 (3): E213-E221.

32 .Hoan NX, Khuyen N, Binh MT, Giang DP, Van Tong H, Hoan PQ et al. Association of vitamin $D$ deficiency with hepatitis $B$ virus - related liver diseases. BMC infectious diseases. 2016; 16 (1): 507.
33. Bi Y, Zhang W, Sun J, Gao R. Therapeutic and immune function improvement of vitamin $D$ combined with IFN- $\alpha$ on mouse with hepatitis B infection. International journal of immunopathology and pharmacology. 2018; 32 : 2058738418775250 .

34 .Yu R, Tan D, Ning Q, Niu J, Bai X, Chen S et al. Association of baseline vitamin $\mathrm{D}$ level with genetic determinants and virologic response in patients with chronic hepatitis B. Hepatology Research. 2018; 48 (3): E213-E221.

35 .Mendes MM, Darling AL, Hart KH, Morse S, Murphy RJ, Lanham-New SA. Impact of high latitude, urban living and ethnicity on 25-hydroxyvitamin D status: A need for multidisciplinary action? The Journal of steroid biochemistry and molecular biology. 2019; 188: 95-102.

36 .Putz-Bankuti C, Pilz S, Stojakovic T, Scharnagl $\mathrm{H}$, Pieber TR, Trauner M et al. Association of 25-hydroxyvitamin D levels with liver dysfunction and mortality in chronic liver disease. Liver international : official journal of the International Association for the Study of the Liver. 2012; 32 (5): 845-851.

37 .Zhao X-Y, Li J, Wang J-H, Habib S, Wei W, Sun $\mathrm{S}-\mathrm{J}$ et al. Vitamin D serum level is associated with Child-Pugh score and metabolic enzyme imbalances, but not viral load in chronic hepatitis B patients. Medicine. 2016; 95 (27): e3926.

38.Wong GL-H, Chan HL-Y, Chan H-Y, Tse C-H, Chim AM-L, Lo AO-S et al. Adverse effects of vitamin D deficiency on outcomes of patients with chronic hepatitis B. Clinical Gastroenterology and Hepatology. 2015; 13 (4): 783-90.e1. 